Academic
$\begin{aligned} & \text { Journal of } \\ & \text { Islamic Studies }\end{aligned}$
Institut Agama Islam Negeri (IAIN) Curup, Indonesia
ISSN 2580-3174, (p); 2580-3190 (e)
volume 6, number 2, 2021 | page: 207-224
DOI: http://doi.org/10.29240/ajis.v6i2.3419

\title{
Islamophobia and Allegations Against Corona Virus Spread By Muslim Minority In India
}

\author{
Muhammad Saekul Mujahidin \\ Universitas Islam Negeri (UIN) Walisongo, Semarang, Indoneisa \\ saiqulmujahidin@gmail.com
}

\begin{abstract}
This article discusses Islamophobia and accusations by the Hindu majority against Muslim minorities in India against the coronavirus. The Bharatiya Janata Party (BJP) is one of the parties that often voices accusations against Muslim minorities in India for this incident. The Tablighi Jamaat in New Delhi is one of the targets and accusations of the Hindu majority against Muslims in India. The purpose of this study is to find out the reasons why Hindus accuse Muslims in India of being the cause of the spread of the coronavirus "Covid-19". This paper uses a qualitative descriptive method with secondary data collection. The data were obtained from literature studies including books, journals, or those related to research. The findings of this study show that Hindus hate Islam for a long time, coupled with the activities of the Tablighi Jamaat which make them hate Muslims even more and accuse them of being the spreaders of the Covid-19 coronavirus. Not only that, the majority of Hindus create hashtags on social media, such as \#CoronaJihad, \#BioJihad or \#MuslimMeaningTerrorist, all of which are used to increase hatred and rally the Hindus community against Muslims in India during the pandemic.
\end{abstract}

Keywords: Islamophobia, Covid-19, Minorities, Muslims, India

\section{Introduction}

The phenomena of Islamophobia in India were recorded as the Kolkata incident in 1964, the Nellie massacre in 1983, the Hashipura massacre in 1987, the Bombay riots in 1992, the Gujarat riots in 2002, the assassination of Muhammad Akhlaq in Badri in 2015, and the assassination of Hafizul Sheikh in Bengal, the Junaid Khan Incident and the killing of Arazul in Rajasthan in 2017. Socio-political and religious factors are also some of the main contributors to the high prevalence of Islamophobia in India. Moreover, the hatred created among Hindus at the time of the separation of power and control in a series of Islamophobic attacks in the form of physical, religious, and sexual attacks against the 
Muslim community in India. ${ }^{1}$ Not only that, the issue of the spread of Covid-19 in India has always been associated with Muslim minorities, that Muslims in India are the masterminds of the spread of the coronavirus outbreak to date.

A wave of Islamophobia has recently resurfaced over Hindu accusations against the Tablighi Jamaat group by Muslims in New Delhi. The gathering has prompted people in India to form anti-Muslim communities with hashtags on social media such as \#coronajihad, \#tablighijamaatvirus. ${ }^{2}$ In addition to the online world, rising Islamophobia is also increasing in real-world hate crimes perpetrated by hardline Hindus against India's Muslim minority. Therefore, the research is more focused on accusations against Hindus against Muslims in India for the increasing spread of the coronavirus "Covid-19", whether the accusations are proven true or false by Hindus against Muslims in India.

In the process of compiling this journal, the researcher uses several previous literature studies in the form of journals as a framework that are still related to discussions in India, especially discussions about Islamophobia and the alleged spread of COVID-19 by Muslim minorities.

The first journal is entitled "Islamophobia In India while The Covid-19 Crisis: A Surge Of Stigmatization, Vilification, And Murder", by Thameem Ushama. The journal documents how fanatic fascists have exploited the Covid-19 pandemic to stigmatize, demonize and persecute Muslims in India.

The second journal is entitled "The "Labeled" Side of Covid-19 in India: Psychosocial Perspectives on Islamophobia in During the Pandemic", by Kanika K. Ahuja \& Debanjan Banerjee, in which the journal discusses the social context of increasing Islamophobia in India during the pandemic, as well as explanations regarding the psychological and health impacts on society during the pandemic.

${ }^{1}$ Ingrid Therwath, "Working for India or against Islam? Islamophobia in Indian American Lobbies", South Asia Multidisciplinary Academic Journal, 2019, 1, https://doi.org/10.4000/samaj.262

2. Mohit Chandra, Manvith Reddy, "A Virus Has No Religion": Analyzing Islamophobia on Twitter During the COVID-19 Outbreak", 1 
Here the researcher does not only discuss the slander of Muslims in the context of the coronavirus pandemic that has been described by Thameem Ushama and Kanika Ahuja, but this research is more on the accusations made by Hindus for the spread of the coronavirus in India by Muslim minorities.

The research method that the author uses this time is the method qualitative descriptive research using secondary data collection techniques, namely data obtained from library research activities which include: books, journals, research related to this research. ${ }^{3}$ Qualitative research is research that is used to investigate, to find, to describe, and to explain the quality or characteristics of social influence that cannot be explained, measured, or described through a qualitative approach, and the results of qualitative research also focus and emphasize meaning, not generalizations. ${ }^{4}$

\section{History and Perpetrators of Islamophobia in India}

Islamophobia and violence against Muslims in India are certainly not new, ${ }^{5}$ as can be seen from the history of the 8th century (712-740) as a campaign for the conquest of the South Asian continent including India, Pakistan, and Afghanistan by the Umayyad dynasty. From the 8th to the 16th centuries, there were frequent conflicts between the Arab and Hindu caliphate in India, in an article published by Violent Internal Conflicts in the Asia Pacific, entitled "Hindu-Muslim Conflict in India in a Historical Perspective by Marc Gborieasu" which explained that the cause of conflict in India is due to the spread of Islam to India in the Middle Ages. On the other hand, British colonialism also contributed to the high Islamophobia

${ }^{3}$ Sugiyono, Metode Penelitian Pendidikan (Pendekatan Kuantitatif, Kualitatif, $R \& D$ ), (Bandung, Jawa Barat: Alfabeta, 2014)

${ }^{4}$ Saryono, Metode Penelitian Kualitatif (Bandung, Jawa Barat: Alfabeta, 2010).

5 Fatih Uenal, Robin Bergh, "The Nature of Islamophobia: A Test of a Tripartite View in Five Countries", Society for Personality and Social Psychology, Jil. 47, (2), 2021, 276, https://doi.org/10.1177/0146167220922643. 
in India due to the separation of Pakistan from India and also because of racial differences. ${ }^{6}$

India's population consists of $80 \%$ Hindu majority and $20 \%$ other ethnic groups, in which Muslims face the dilemma of Islamophobia and hate crimes in the country. ${ }^{7}$ Vinayak Damodar Savarkar (1883-1966), Keshav Baliram Hedgewar (1889-1940), Madhav Sadashiv Golwalkar (1906-1973), and Bal Thackeray (1926-2012) were the masterminds of Islamophobic actors in twentieth-century India, for their speeches about them hatred against Muslims and related and offensive writings against Muslims during this period. ${ }^{8}$

Muslims in India make up about $12 \%$ of the total population in India. They have a consensus on the ideology of their monolithic religion. The Muslim monolithic religious ideology is completely different from the Hindu majority religious ideology. ${ }^{9}$ Moreover, the power struggle has become a central point in the Muslim-Hindu antagonism which has turned them into mutually hostile groups. Hindu fanaticism arises because of the desire to recreate the past glory, namely the glory of the Hindu Marathan kingdom in India which is the main goal of Hindus in India. This was done by expelling the British invaders from India, but on the other hand, they also wanted to destroy the Muslims in India.

The poet Vinayak Damodar Savarkar's Hindu nationalist philosophy of Hindutva focuses on Hindu solidarity regardless of the consequences. ${ }^{10}$ As president of the Hindu Mahasabha, Savarkar carried the slogan "Hinduize all politics and Militarize Hinduism" for anti-Muslim

${ }^{6}$ Zehra Mehdi, "Phobia of Religion: Religion as Islam a Politicalargument and a Psychoanalytic inquiry of Islamphobia in India", Departement of Religions (Sount Asia of Religions), Columbia University, 2017, 228, https://doi.org/10.1002/aps.1535.

${ }^{7}$ Juan, J. Chamie \& Boris Mirkin, Busting at the seams: India is unprepared for a near future when it will be the world"s most populous country. United Nations Population Division. 2017. 2009, 14-15

8 Jean Christophe, Hindu Nationalism: A Reader, Princeton University Press,

9 Debashis Bandyopadhyay, Madrasa education and the condition of Indian Muslims. Economic and Political Weekly 2002, 1481-1484.

${ }^{10}$ Bipan Chandra, India's Struggle for Independence (New Delhi: Penguin Books, 1989), 145. 
and anti-Christian politics during the Second World War. He sowed the seeds of hatred against Muslims, he also believed that "Hindus in Hindustan are a nation, and others are a community and numerically only a minority". ${ }^{11}$ As a result, Savarkar excludes two religious people namely Muslims and Christians from the country of India, because they do not accept India as a "holy land".

The Mahasabha Party and the Rhastrya Swayam Sevak Sangha organization are fanatical parties founded with the aim of reacting against Muslim institutions in India. The conflict that occurred in India does not only occur in the realm of religion, but also from a social and economic perspective. Hindu society in India believes that all aspects of life are determined by social life. Mahatma Gandhi stated that religion does not see a difference. Religion for Gandhi is the relationship between man and his God. Therefore Gandhi did not want a gulf between Hinduism and Islam in India. ${ }^{12}$

Bal Thackeray, the founder of Shiv Sena, suggested a political model that would persecute and kill minorities en masse as Nazi Adolf Hitler did. In 2008, Thackeray wrote that Islamic terrorism was growing and Hindu terrorism was the only alternative to counter it. He ordered Hindu suicide bombing groups to destroy Muslims like the Israeli operation in Palestine. He also demanded that Indian Hindus should always unite to cross language barriers so that all would see "a Hindustan for Indian Hindus and bring Muslims in this country to their knees".13

Since the re-emergence of Hindu nationalism, right-wing hardliners have become increasingly bold in promoting Hindu dominance and marginalizing Muslims in India. Muslims in India have always experienced discrimination and disadvantage in various areas of life, and this fact has been repeatedly proven by various surveys and reports. We have to admit that the problems faced by Muslims in India because they

11 Vinayak Damodar Savarkar, Hindutva, Who is a Hindu (New Delhi: Bharati Sahitya Sadan, 1989), 3

12 Guruh Prasetyo, Marjono, Sumarjono, "The Assassinaton of Mahatma Gandhi in 1948", Jurnal Historica, Volume 2, Isuue 1, 2018, 41, https://jurnal.unej.ac.id/index.php/JHIS/article/view/7812.

13 Vinod J. S, Balasaheb Thackeray. North Carolina: LP Inc. Google Bdeliver the speech books 2015, 34 
are simultaneously facing problems related to identity, security, and equality. ${ }^{14}$ William W. Hunter in 1969 in his work, "The Indian Musalmans", explained that Indian Muslims have always faced exclusion in their various jobs, and they are also not part of the ranks of officers in the state army, nor do they hold important positions in a job and they are often expelled from their jobs.

According to Indian historian and writer Ramachandra Guha, Muslims, Christians, and Communists were the main threat to the formation of a Hindu state. He once said, "Hindus, don't waste your time fighting the British, instead save your energy against our internal enemies, namely Communists, Islam, and Christianity. Those religions were not born in India, they are similar to Satan, and Hindus are destined to become angels of vengeance who will kill them all (Islam and Christianity)." 15 He also questions the loyalty of Muslims to India. He remains skeptical of their patriotism which causes Hindus to doubt Islam, he openly states that "No power on earth can hold Muslims in Hindustan. They should get out of this country".16

One of the Dharm Jagran Samiti (DJS) officials, Rajeshwar Singh, on 14 December 2014 also stated that "Muslims and Christians must convert to Hinduism if they want to live in this country. Our target is to make India a Hindu Rashtra by 2021. Muslims and Christians have no right to live here. So, they can stay in India but must convert to Hinduism or be forced to leave India. I will ensure that India will be liberated from Muslims and Christians by 31 December 2021. This is a promise taken by me and my colleagues; this is a promise to all of us."

${ }^{14}$ Justice Raghenth Basant \& Azim Shariff, Handbook of Muslims in India. Oxford: Oxford University Press. 2009, 2

15 Ramachandra Guha, Makers of Modern India, (New Delhi: Penguin Books, 2013)

16 Thameem Ushama, "Islamophobia in India During the Covid-19 Crisis: A Surge of Stigmatization, Vilification and Murder" Al-Shajarah, ISTAC, Journal of Islamic Thought And Civilization, Vol 6, No 1, (2021), 75, 
Under Prime Minister Narendra Modi's BJP (Bharatiya Janata Party) government, ${ }^{17}$ Muslims in India have always been marginalized and felt the most humiliated in the history of the secular and plural society of the country, which has been dubbed the world's largest democracy. Since independence in 1947, Hindus killed and arrested Muslims for eating beef or transporting cows, because cows are animals that are sacred by the majority of Hindus in India.

In a 2016 speech, the State Minister for Skills Development and Entrepreneurship BJP (Bharatiya Janata Party) stated that: "As long as there are Muslims in this world, there will be terrorism. Until we eliminate Muslims, we cannot eliminate terrorism." Then in 2019, BJP President Amit Shah promised, "We will ensure the implementation of the NRC (National Register of Assamese Citizens) throughout the country. We will remove all intruders from India countries, except Hindus, Sikhs, and Buddhists."

\section{Controversial Anti-Muslim Law}

The new history of Islamophobia began after one of the international tragedies between religions caught the world's attention. It was the news about riots between Hindus and Muslims in New Delhi, India that occurred on 23-26 February 2020. The initial riots occurred on 23 February, 2020 when Indian Prime Minister Narendra Modi approved the Anti-Muslim Law or Citizenship Amendment Bill (CAB) two months ago. ${ }^{18}$

Deadly protests are widespread across India because of the highly controversial Indian Citizenship law, which corners India's Muslim minority. The following is the contents of the Citizenship Amendment Bill (CAB) dated December 12, 2019, which reeks of discrimination against Muslims in India: "In the Citizenship Act 1955 (hereinafter referred to as

17 Prashant Waikar, "Reading Islamophobia in Hindutva: An Analysis of Narendra Modi's Political Discourse”, Islamophobia Studies Journal , Vol. 4, No. 2 (Spring, 2018), 169, https://doi.org/10.13169/islastudj.4.2.0161.

${ }^{18}$ Dwi Putri Robiatul Adawiyah \& Agoes Moh. Moefad, "Reality Construction and Framing Analysis of the News Coverage of Muslim-Hindu Riots in India on CNN.Com Online Media", Orasi, Jurnal Dakwah dan Komunikasi, Volume 11 No. 2 Desember 2020, 150, https://doi.org/10.24235/orasi.v11i2.6601. 
Basic Law), in section 2, in paragraph (1), in paragraph (b), applies the following provisions: "Provided that any person who is a Hindu, Sikh, Buddhist, Jain, Parsi or Christian from Afghanistan, Bangladesh or Pakistan, who enters India on or before the 31st day of December 2014 and who has been excluded by the Central Government by or according to clause (c) subsection (2) of Article 3 of the Passport (Entry to India) Act, 1920 or from the application of the provisions of the Foreigners Act, 1946 or any regulation or order made thereunder, shall not be treated as a migrant illegal for this Act;".19

The Citizenship Amendment Bill (CAB) was first introduced in July 2016, which was the result of an amendment to the Citizenship Law (CAB) in 1955 which stipulates that the basis for obtaining citizenship rights is religion. The citizenship law mentions various layers of religion, but Islam is not mentioned, and it cannot be denied that people who embrace Islam in India is about $14 \%$ of Indian. 1.3 billion of Indian population are Hindus, the rest are Christians, Buddhists, and other faiths. As a result of the enactment of the law, there have been serious clashes between demonstrators and local police in eastern India. Police reportedly used firearms and opened fire to disperse protesters, the riots left at least two people dead and several others injured.

The government led by the Hindu nationalist Bharatiya Janata Party (BJP) argues that the law is a form of protection for Indian citizens against foreigners who are victims of "persecution in the name of religion". However, under this law, Muslims in India are required to prove that they are indeed citizens of India, so there is a possibility that Indian Muslims will lose their citizenship status for no reason. Worse yet, this rule does not apply to other religions, because there is no clear line in the law.

The law, which has been a source of chaos, is part of Prime Minister Narendra Modi's Hindu nationalist agenda. Islamic groups, the opposition, and human rights groups say the law aims to marginalize at

${ }^{19}$ R. Yahdi Ramadani, "Diskirminasi Kaum Muslim di India Menurut Konvensi Hak Asasi Manusia" Journal Inicio Legis Vol 1, No 1 Oktober (2020), 6, https://doi.org/10.21107/il.v1i1.8823. 
least 200 million Muslims in India. India's upper house of parliament then held a vote to pass this law on 11 December 2019, which resulted in 125 votes in favor and 105 votes against. Two days earlier, the bill had been passed by the lower house. Currently, there are at least 700 figures in India, consisting of various layers such as legal experts, academics, and actors, who have signed a firm statement rejecting the highly controversial law.

Jamia Millia Islamia University students staged a demonstration that ended in clashes with the police. It is not clear who started the commotion, but a stone object was thrown at police, who responded by firing tear gas. Local media reported that nearly 60 people, including students and police, were injured and that at least three buses and several motorbikes were set alight by protesters. The students insisted they were not involved in the violence and some police officers privately admitted that local criminals were the perpetrators, the BBC's journalists report. The university said police had just entered the campus environment without local permission, then eventually attacked campus staff and students. Police argue that they have done what was necessary to stop the ongoing protests. Schools located near campuses in the south of the capital have been asked to temporarily suspend teaching and learning activities.

In December 2020, Police in North India arrested at least 10 Muslim men for allegedly converting his wife to Islam after marrying them. Police arrested the men under the country's new anti-conversion laws. 10 people arrested were from different parts of Uttar Pradesh. Uttar Pradesh was the first province in India to pass a law prohibiting religion by force or trickery. According to the law, India provides a prison sentence for someone who forces another person to convert or persuade them to convert through marriage.

The highly controversial law does not specify any religion. However, critics say the law is merely an Islamophobic symbol of India's hardline Hindu rulers. Later, officials in Uttar Pradesh argued that the law would help preventing fake conversion attempts because it is designed to protect girls in India, as the government of Uttar Pradesh is controlled by 
the Hindu nationalist Bharatiya Janata Party BJP, Prime Minister Narendra Modi's party.

\section{Alleged Spread of Covid-19 by Muslim Minorities in India}

Before the outbreak of the coronavirus, India was not a safe place for India's Muslim minority led by Narendra Modi. Insecurity among Muslims has always increased sharply after the alleged spread of the coronavirus. Narendra Modi also supports the product of religious nationalism which sees India as a fundamental Hindu religious state and rejects the Nehruvian secularism promoted by the nation's founders. ${ }^{20}$

A wave of Islamophobia has recently emerged across India during the spread of Covid-19 after a Muslim congregation was attacked over the alleged increase in cases of the coronavirus. ${ }^{21}$ The acclaimed US newspaper, the Washington Post, strongly condemned the Indian state for incidents that have always scapegoated India's Muslim minority, arguing that "The search for scapegoats during the coronavirus pandemic has focused squarely on the country's sizable Muslim minority, a society that having a Population of 200 million people felt threatened even before the advent of Covid-19."

The Gulf News 2020 website addresses the spread of miscommunication targeting India's Muslim minority. Gulf News reports that "Over the past two months, the AFP fact-checking team has uncovered hundreds of social media posts falsely targeting Muslim minorities as carriers of the Covid-19 pandemic in India, with the hashtag \#Corona_Jihad launched to target Muslim minorities in India.

\footnotetext{
${ }^{20}$ Natalia Zajaczkowska, "Hindu-Muslim Relations in Times of Corona Virus", Studia Orientalne, $\mathrm{Nr} 2$, (18), University of Lodz 2020, 82, https://doi.org/10.15804/so2020206.

21 Zaeem Yasin, Hassan Siddique, dkk, "Arab World's Criticism on Indian Islamophobia: Understanding Islamic Perspective”, Global Political Review, Vol. V, No. IV (Fall 2020), 50, https://doi.org/10.31703/gpr.2020(V-IV).06.
} 

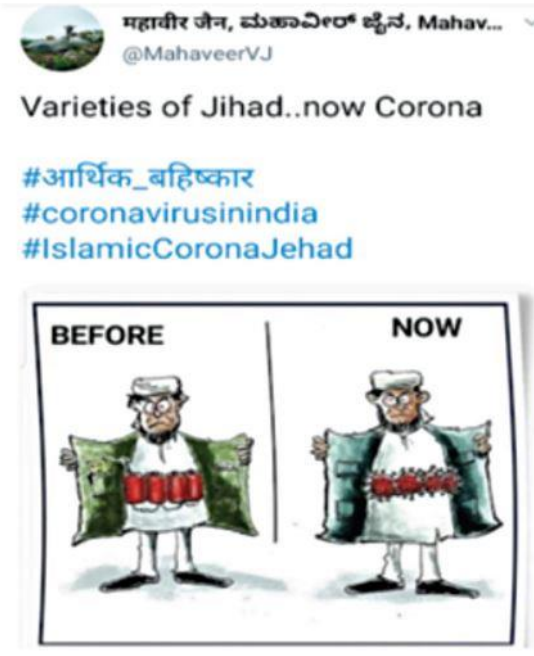

Picture 1. A caricature posted on Twitter shows a Muslim terrorist replacing a suicide bomber vest with the coronavirus

The wave of Islamophobia in India is increasing along with a series of cases of contagion at the Tablighi Jamaat headquarters in New Delhi, where a large event was held which was attended by thousands of Muslims, including from Indonesia. Later, the event was exploited by hardline Hindu nationalism groups to accuse and mobilize anti-Muslim campaigns on social media, with hashtags such as \#Coronajihad, \#Biojihad, or \#MuslimMeaningTerrorist, all of which were used to spread conspiracy theories used by the hardline Hindu majority as weapons against Muslim minorities across India. 


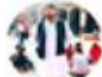

Sanyam Jain

(a)modivanibharat

This \#TablighiVirus has caused a coronavirus explosion in Delhi \& yet playing victims.

\section{Bloods of many will be in your hands Nizamuddin Makraz...}

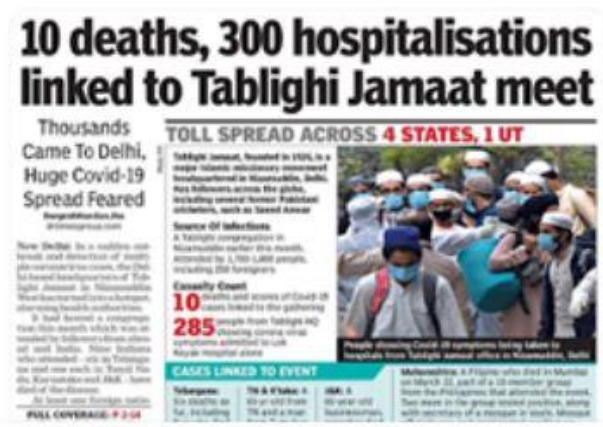

Picture 2. Image of a person accusing the Tablighi Jamaat of causing the spike in the coronavirus in New Delhi. ${ }^{22}$

As Covid-19 began to spread in India, and New Delhi in particular, some media reports began to portray that the coronavirus outbreak in Delhi was the actor of the Tablighi Jamaat association. Not only that, the police filed a complaint against seven people, including the emir of the Tablighi Jamaat, for being accused of murder. Two Indian diaspora organizations in the United States, namely "The Indian American Muslim Council" (IAMC) and "Hindus For Human Rights" (HfHR) issued a joint statement condemning and blaming Muslim minorities for the coronavirus outbreak, especially through the Tablighi Jamaat association. According to the group, the Covid-19 crisis is being used by those in power to sharpen the religious conflict between Hindus and Muslims in India.

Quoted from Al-Jazeera in 2020 reported that India's ruling party, namely the Bharatiya Janata Party (BJP), "issued a fatwa to one of its leaders after a video showing him asking someone not to buy vegetables

22 Shweta Desai and Amarnath Amarasingam, \#Corona Jihad Covid -19, Misinformation, and Anti Muslim Violence in India, ISD London Washinton DC Beirut Toronto, 4 
from Muslim traders appeared in the middle nationwide Covid-19 lockdown in India". Not only that, but Al-Jazeera also reported that the separation between Muslim and Hindu Covid-19 patients in the state of Gujarat. Then Arab News also regretted the stigmatization of the Muslim missionary group Tabligh Jamaat and called this incident one of many examples of increasing marginalization of Muslims. In the same article, Arab News also quotes the thoughts of Dr. Hilal Ahmed in New Delhi, states that "The growing polarization is certainly affecting the daily life of the Muslim community in India".23

Extreme Hindus have exploited the coronavirus crisis in recent days by accusing Muslims of opposing the state and attacking them. In February, New Delhi also witnessed deadly attacks by Hindu extremists against its Muslim minority that killed at least 54 people. The Indian government's policy of implementing controversial laws in cracking down on and violating the rights of Muslims in India has led extreme Hindus to carry out sporadic and lethal acts against Muslim minorities with the support of the current ruling BJP party. The burning by hardline Hindus of ten mosques and Muslim holy sites in India is inhumane and anti-Islamic over the past two months. According to eyewitnesses, Indian police and state security forces witnessed only the violent incident.

The Bhartiya Janata Party (BJP) is suspected of being the mastermind and actor of accusations and oppression of Muslim minorities during the pandemic. Therefore the BJP is very easy to lead opinion to the Hindu community in India to hate Islam so that the Muslim minority finds it difficult to fight against it, at that time the Bhartiya Janata (BJP) was the ruling party in India led by Prime Minister Narendra Modi.

Before the Covid-19 outbreak, tensions had already begun to emerge over the recently passed 2019 Citizenship Amendment Act to isolate Muslims, resulting in nationwide protests. In February, India witnessed the worst violence between Hindus and Muslims in decades. Some fake news and conspiracy theories have also emerged to accuse

23 Zaeem Yasin, Hassan Siddique, dkk, “Arab World's Criticism on Indian Islamophobia: Understanding Islamic Perspective”, Global Political Review, Vol. V, No. IV (Fall 2020), 52, https://doi.org/10.31703/gpr.2020(V-IV).06. 
Muslims of carrying out a malicious campaign to spread Covid-19 among India's Hindu majority, which has resulted in demonization, denial of medical treatment, boycotts, and attacks on Muslims across India. ${ }^{24}$

Indian Intellectuals, Human Rights Defenders, and 101 former Indian civil servants called on state authorities in an open letter to defend discriminated Muslim minorities, Indian Intellectuals emphatically articulated that religious minorities are not responsible for the spread of the coronavirus pandemic in India: "We know where this virus came from. We know this is a pandemic that is being experienced in parts of the world. This is not something that results from the presence of religious minorities in India." Then as Arjun Appadurai, Anthropologist from New York University said that: "One of the main features of anti-Muslim sentiment in India for a long time has been the idea that Muslims themselves are a kind of infection within the body of politics. So there's a kind of closeness between the old image and the new anxiety surrounding the coronavirus pandemic."

Human Rights Watch has expressed concern over rising Islamophobia in India. Correspondingly, India has also attracted international criticism. Recently, the United States Commission on International Religious Freedom urged the State Department to designate India as a "country of particular concern" for the "gross violation" of religious freedom, India's worst since 2004. Likewise, the Organization of Islamic Cooperation (OIC), including the Kuwaiti government, the royal princess of the United Arab Emirates, as well as several Arab state activists, many of whom are strategic and trade partners of India, have expressed deep concern over speech from an Indian accusing the country's Muslims of being behind the Covid-19 outbreak and Islamophobic hatred.

\section{Conclusion}

24 Nazneen Mohsina and Joseph Franco, "Rising Islamophobia in India: Exploiting the Pandemic", Nanyang Tehnological University, Singapore, RSIS, Rajaratnam School of International Studies, No 109, Vol 3, Juni (2020), 2, https://hdl.handle.net/10356/143688. 
From the explanation above, the author concludes that the wave of Islamophobia in India existed long before the outbreak of the coronavirus disease (Covid-19), and was exacerbated by the Tablighi congregation carried out by Muslims in India. This incident gives hardline Hindus an opportunity to accuse and corner the Muslim minority as the perpetrators of the corona disease outbreak. Not only that, the majority of hardline Hindus also creates hashtags on social media so that Hindu hatred towards Muslims is increasing. In addition, and what is even worse is that there is a controversial law, namely the law that marginalizes Muslims in India. This makes Muslim minorities as targets of violence across India, especially in New Delhi as Hindu majority is consumed by untrue news.

\section{Bibliography}

Adawiyah, D.P. Robiatul \& Agoes Moh. Moefad, "Reality Construction and Framing Analysis of the News Coverage of Muslim-Hindu Riots in India on CNN.Com Online Media", Orasi, Jurnal Dakwah dan Komunikasi, Volume 11 No. 2 Desember 2020, https://doi.org/10.24235/orasi.v11i2.6601.

Al-Zaman, Sayeed, "Politics meets healthcare? Religious misinformation in India during the COVID-19 pandemic", Jurnal Sosial Humaniora (JSH), Volume 13, ed.2, 2020, https://dx.doi.org?10.12962/i24433527.v13i2.8119.

Bandyopadhyay, Debashis, Madrasa education and the condition of Indian Muslims. Economic and Political Weekly 2002

Basant, J. Raghent and Azim Shariff, Handbook of Muslims in India. Oxford: Oxford University Press. 2009

Chamie, Juan, J. \& Boris Mirkin, Busting at the seams: India is unprepared for a near future when it will be the world"s most populous country. United Nations Population Division. 2017.

Chandra, Bipan, India's Struggle for Independence (New Delhi: Penguin Books, 1989)

Chandra, Mohit, Manvith Reddy, "A Virus Has No Religion": Analyzing Islamophobia on Twitter During the COVID-19 Outbreak". 
Christophe, Jean, Hindu Nationalism: A Reader, Princeton University Press, 2009.

Desai, Shweta and Amarnath Amarasingam, \#Corona Jihad Covid -19, Misinformation, and Anti Muslim Violence in India, ISD London Washinton DC Beirut Toronto,

Guha, Ramachandra, Makers of Modern India, (New Delhi: Penguin Books, 2013)

Mohsina, Nazneen, and Joseph Franco, "Rising Islamophobia in India: Exploiting the Pandemic", Nanyang Technological University, Singapore, RSIS, Rajaratnam School of International Studies, No 109, Vol 3, Juni (2020), https://hdl.handle.net/10356/143688.

Mehdi, Zehra, "Phobia of Religion: Religion as Islam a Politicalargument and a Psychoanalytic inquiry of Islamophobia in India", Departement of Religions (South Asia of Religions), Columbia University, 2017, https://doi.org/10.1002/aps.1535.

Prasetyo, Guruh, Marjono, Sumarjono, "The Assassination of Mahatma Gandhi in 1948", Jurnal Historica, Volume 2, Issue 1, 2018, https://jurnal.unej.ac.id/index.php/JHIS/article/view/7812.

Ramadani, R. Yahdi, "Diskirminasi Kaum Muslim di India Menurut Konvensi Hak Asasi Manusia" Journal Inicio Legis Vol 1, No 1 Oktober (2020), 6, https://doi.org/10.21107/il.v1i1.8823.

Saryono, Metode Penelitian Kualitatif (Bandung, Jawa Barat: Alfabeta, 2010)

Savarkar, V. Damodar, Hindutva, Who is a Hindu (New Delhi: Bharati Sahitya Sadan, 1989)

Sugiyono, Metode Penelitian Pendidikan (Pendekatan Kuantitatif, Kualitatif, R\&D) (Bandung, Jawa Barat: Alfabeta, 2014)

Thackeray, V. J. S, Balasaheb. North Carolina: LP Inc. Google B delivers the speech books 2015

Therwath, Ingrid, "Working for India or against Islam? Islamophobia in Indian American Lobbies", South Asia Multidisciplinary Academic Journal, 2019, https://doi.org/10.4000/samaj.262. 
Uenal, Fatih, Robin Bergh, "The Nature of Islamophobia: A Test of a Tripartite View in Five Countries", Society for Personality and Social Psychology, Jil. 47, (2), 2021, https://doi.org/10.1177/0146167220922643.

Ushama, Thameem, "Islamophobia in India During the Covid-19 Crisis: A Surge of Stigmatization, Vilification and Murder" Al-Shajarah, ISTAC, Journal of Islamic Thought And Civilization, Vol 6, No 1, (2021)

Waikar, Prashant, "Reading Islamophobia in Hindutva: An Analysis of Narendra Modi's Political Discourse", Islamophobia Studies Journal, Vol. 4, No. 2 (Spring, 2018), https://doi.org/10.13169/islastudj.4.2.0161.

Yasin, Zaeem, Hassan Siddique, "Arab World's Criticism on Indian Islamophobia: Understanding Islamic Perspective", Global Political Review, Vol. V, No. IV (Fall 2020), https://doi.org/10.31703/gpr.2020(V-IV).06.

Zajaczkowska, Natalia, "Hindu-Muslim Relations in Times of Corona Virus", Studia Orientalne, $\mathrm{Nr} 2$, (18), University of Lodz 2020, https://doi.org/10.15804/so2020206. 
224 | AJIS : Academic Journal of Islamic Studies, vol. 6, no. 2, 2021

Empty page 